\title{
Phasing of autotrophic and heterotrophic plankton metabolism in a temperate coastal ecosystem
}

\author{
Stephen P. Blight, Tracy L. Bentley, Dominique Lefevre, Carol Robinson, \\ Rubina Rodrigues, John Rowlands, Peter J. leB. Williams,***
}

University of Wales, Bangor, School of Ocean Sciences, Menai Bridge, Gwynedd LL59 5EY, United Kingdom

\begin{abstract}
Plankton abundances, bacterial production, and the size distribution of oxygen metabolism and chlorophyll a concentration were determined through 3 seasonal cycles in the Menai Strait (North Wales, UK) Spring blooms were comprised of a diatom to Phaeocystis succession. Meso- and microphytoplankton dominated phytoplankton production and biomass during diatom blooms, and nanophytoplankton predominated during summer, when activity and biomass were low. Correlation analysis showed temperature to be the best predictor for chlorophyll a-specific gross community production. Bacterioplankton were implied to be the major respirers. Consequently the phasing of respiration in relation to photosynthesis was strongly influenced by bacterioplankton metabolism and abundance changes. The respiration maximum occurred 1 to 2 wk after the Phaeocystis abundance maximum. An explanation for this temporal lag was sought by considering the time scales of flow of organic material between the phytoplankton and the bacterioplankton. The observations were consistent with routes via a slowly cycling pool, such as polymeric organic material. This pool would function as a reservoir and result in microheterotrophic respiration persisting after the decline of photosynthesis, and causing a positive to negative temporal sequence in net community production.
\end{abstract}

KEY WORDS: Plankton - Autotrophic Heterotrophic Photosynthesis - Respiration - Phasing - Bacteria - Diatom - Phaeocystis

\section{INTRODUCTION}

The coastal water regions are areas of high primary production in the ocean. Although these waters constitute less than $10 \%$ of global ocean area, they account for $25 \%$ of the total oceanic primary production (Berger et al. 1989). The effect of this elevated primary production on the process of net deposition is magnified by its pulsed nature (e.g. the spring bloom in temperate coastal waters) and the proximity of the benthos (Berger et al. 1989). Consequently, coastal sediments are an important sink for carbon and the magnitude of this sink may be increasing as eutrophication of coastal waters continues (Kempe \& Pegler 1991). Therefore, characterization of the production and loss processes for coastal plankton is important if we are to under-

\footnotetext{
•E-mail: oss074@bangor.ac.uk

" All authors other than the first are listed alphabetically
}

stand the role of coastal waters in the global carbon cycle.

The most ubiquitous loss process is respiration. Size fractionation studies have shown this process to be dominated by the smaller size fractions, especially the heterotrophic bacterioplankton (e.g. Williams 1981, Harrison 1986). Consequently, the phasing of photosynthesis and respiration will be strongly influenced by the nature of the links between the phytoplankton and the bacterioplankton. One link occurs via a dissolved organic matter (DOM) pool that can be considered as comprised of 2 pools. One, utilizable monomers and oligomers, i.e. low molecular weight material (LMW), is rapidly turned over by the bacterioplankton (e.g. Fuhrman 1987). The other is comprised of polymers, i.e. high molecular weight material (HMW) and must be hydrolysed before utilization by the bacterioplankton (Chróst 1990a); the hydrolytic step is believed to be rate limiting (Chróst 1990b) and so this 
pool turns over more slowly (e.g. Billen 1990). Thus, pathways via the HMW pool give rise to a looser coupling between photosynthesis and bacterial respiration, with the respiration response more protracted. This would allow for the temporal extension of bacterial respiration beyond the decline of photosynthesis

The aim of this study was to determine the phasing of community photosynthesis and respiration during the temporal evolution of phytoplankton blooms and in the analysis of the data to address the basis of this phasing.

\section{METHODS}

Sampling. Water was collected from St. George's pier, Menai Bridge (North Wales, UK; Fig. 1) over the period of January 1992 to June 1994. During 1992, $5 \mathrm{dm}^{3}$ water samples were collected in the morning, irrespective of tidal state, from a depth of $1 \mathrm{~m}$ using a Niskin bottle, at 30 to 35 d intervals during autumn and winter months and at 5 to $8 \mathrm{~d}$ intervals during the more productive spring and summer months. In 1993 and 1994, 100 to $150 \mathrm{dm}^{3}$ of water was drawn through a $200 \mu \mathrm{m}$ mesh from a depth of $1 \mathrm{~m}$ using a hand bilge pump ( $5 \mathrm{dm}^{3} \mathrm{~min}^{-1}$ ) and collected in $50 \mathrm{dm}^{3}$ opalescent polypropylene aspirators. During 1993, sampling was undertaken before dawn and within $2 \mathrm{~h}$ of high water at $14 \mathrm{~d}$ intervals during spring and summer and at 28 to 42 intervals during autumn and winter. In 1994, samples were collected before noon and within $2 \mathrm{~h}$ of high water every 6 to $13 \mathrm{~d}$. Additionally, in 1994 unfractionated samples were obtained by immersing and filling a $10 \mathrm{dm}^{3}$ opalescent polypropylene aspirator, avoiding the surface microfilm. Air temperature was obtained from the nearest meteorological station (Valley, Fig. 1).
In 1994, a Secchi disc was used to estimate the vertical attenuation coefficient for downward irradiance $\left(k_{d}\right)$ and the relationship $k_{\mathrm{d}} Z_{\mathrm{s}}=1.45$, where $Z_{\mathrm{s}}$ denotes Secchi depth used to calculate $k_{d}$ (Walker 1980).

Size fractionation. Custom made, gravity driven, large diameter (142 mm) reverse flow filtration systems were used in parallel to perform most of the 1993 and all of the 1994 fractionations $(<200,<53,<20$, and $<0.8 \mu \mathrm{m}$ ). During the 1993 Phaeocystis bloom, a crossflow filtration unit (Amicon, USA) was used to prepare the $<0.8 \mu \mathrm{m}$ size fraction. Nylon meshes were used for separating the $<200,<53$ and $<20 \mu \mathrm{m}$ fractions; polycarbonate filters (Poretics Inc., Livermore, CA, USA) for the $<0.8 \mu \mathrm{m}$ fraction. All fractionations were performed outdoors, shielded from direct sunlight and completed within $4 \mathrm{~h}$ of sampling.

Oxygen flux measurements. Dissolved oxygen concentrations were determined by Winkler titrations using a PC-based system with a photometric endpoint detector (Williams \& Jenkinson 1982). Borosilicate glass bottles (50 to $150 \mathrm{~cm}^{3}, 3$ to 6 replicates) were used to perform light and dark bottle incubations for $8 \pm$ $0.5 \mathrm{~h}$ (1992) and $24 \pm 0.5 \mathrm{~h}$ (1993 and 1994) in outdoor water cooled light and dark incubators; the temperature was not greater than $3^{\circ} \mathrm{C}$ above in situ water temperature. For all incubations the oxygen concentration was measured at the start and end of the incubation. In addition, intermediate time points (every 2 to 4 h) were measured on 2 separate occasions to follow the time course of respiration. In 1993 and 1994, the incubation light intensity was attenuated to $60 \%$ of total incident solar radiation by a neutral density mesh.

Tritiated thymidine incorporation (TTI). The incorporation of ${ }^{3} \mathrm{H}$-methyl thymidine into ice-cold trichloroacetic acid (TCA) insoluble material was used to estimate heterotrophic bacterioplankton production

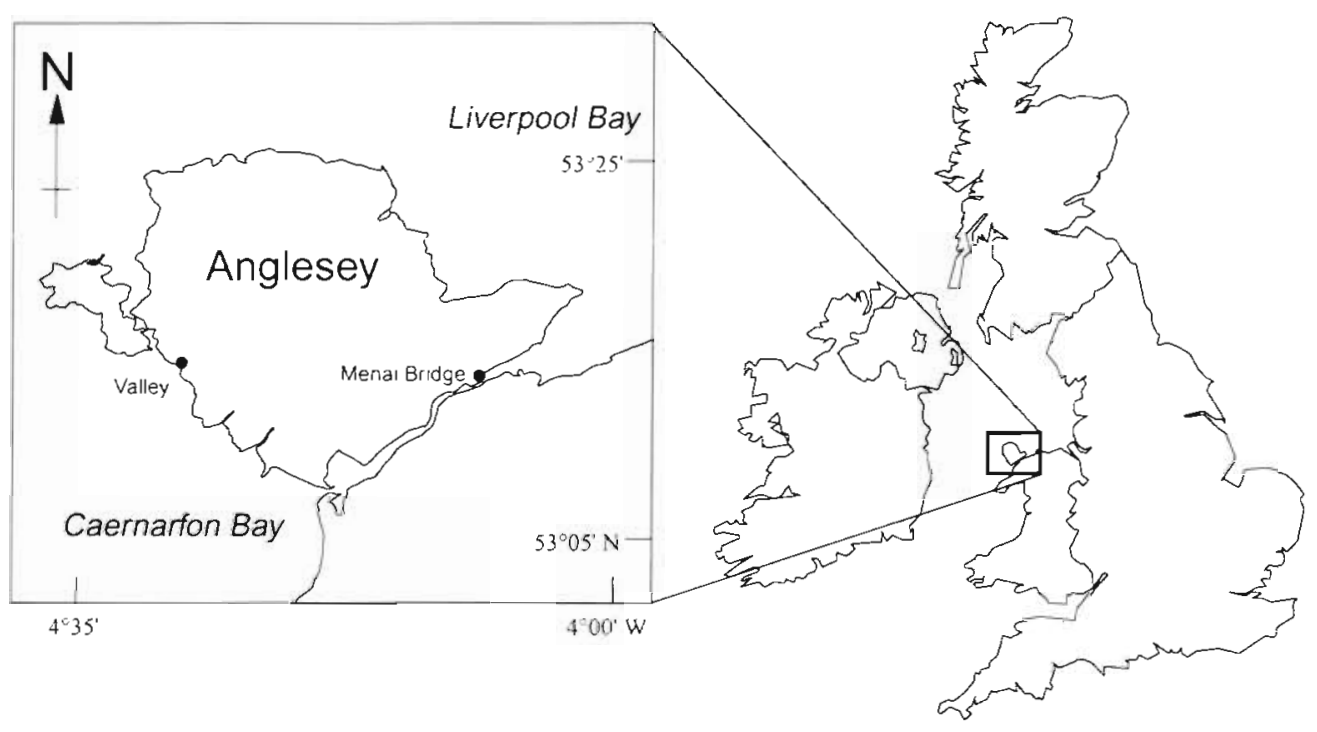

Fig. 1. Map of sample area 
(Fuhrman \& Azam 1980). ${ }^{3} \mathrm{H}$-methyl thymidine (Amersham, specific activity $84 \mathrm{Ci} \mathrm{mmol}^{-1}$, final concentration $5 \mathrm{nM}$ ) was added to subsamples in sterile tissue culture tubes and incubated for $1 \mathrm{~h}$. Two replicates $\left(10 \mathrm{~cm}^{3}\right)$ were made along with a formalin-killed blank. Additional time course experiments were occasionally performed and thymidine incorporation was always found to be linear over at least $2 \mathrm{~h}$. Thymidine incorporation was halted by the addition of formaldehyde $\left(0.5 \mathrm{~cm}^{3}, 1 \%\right.$ final concentration) and within $12 \mathrm{~h}$ macromolecular material was precipitated by adding $1 \mathrm{~cm}^{3}$ of ice-cold $20 \%$ TCA and leaving the samples to stand on ice for 15 min (Wicks \& Robarts 1987). The precipitates were then collected on $0.2 \mu \mathrm{m}$ polycarbonate filters (Ducklow et al. 1992; Poretics Inc.), washed twice with $1 \mathrm{~cm}^{3}$ of ice-cold $5 \%$ TCA and once with $5 \mathrm{~cm}^{3}$ of ice-cold $80 \%$ ethanol to remove unincorporated label. The filters were dissolved in $4 \mathrm{~cm}^{3}$ of Optiphase scintillation cocktail in minivials and counted with a Packard Tricarb series scintillation counter. The obtained counts were converted to disintegrations by the external standard method.

A conversion factor experiment was performed on Day 130 of 1994 . The $<0.8 \mu \mathrm{m}$ fraction was diluted approximately 5 -fold with seawater filtered through a $0.2 \mu \mathrm{m}$ membrane disc (Anotec, UK). This diluted sample was incubated in a $2.5 \mathrm{dm}^{3}$ polycarbonate bottle within $1{ }^{\circ} \mathrm{C}$ of in situ water temperature. Subsamples were taken every $4 \mathrm{~h}$ over $36 \mathrm{~h}$ for the determination of the thymidine incorporation rate and bacterial numbers. The conversion factor was derived by dividing the increase in bacterial numbers over the incubation period by the integrated thymidine incorporation, as recommended by Bell (1988).

Micro- and nanoplankton (Sieburth et al. 1978) counts and biovolume estimates. Subsamples were collected in glass medical bottles $\left(50\right.$ to $\left.100 \mathrm{~cm}^{3}\right)$ into which 4 to 8 drops of acid Lugols (Throndsen 1978) had been pipetted and the bottles stored at $4^{\circ} \mathrm{C}$. Aliquots $\left(10\right.$ to $\left.50 \mathrm{~cm}^{3}\right)$ were allowed to settle overnight in sedimentation chambers before counting the plankton by inverted microscopy (Utermöhl 1958). Cell volumes were estimated according to basic steriometrical formulas (Edler 1979).

Bacterial numbers. Subsamples $\left(50 \mathrm{~cm}^{3}\right)$ were fixed with $50 \%$ glutaraldehyde solution (final conc. $0.5 \%$ ) and stored at $4^{\circ} \mathrm{C}$. Within $24 \mathrm{~h}, 3$ to $5 \mathrm{~cm}^{3}$ of the subsamples were stained for 6 min with the DNA stain DAPI (Porter \& Feig 1980; final conc. $1.25 \mathrm{\mu g} \mathrm{cm}^{-3}$, Sigma, USA), filtered down onto $0.2 \mu \mathrm{m}$ polycarbonate filters (Poretics Inc.) and stored at $-20^{\circ} \mathrm{C}$ until counted. Measurements of bacterial numbers (minimum of 400 cells or 30 grids) were made with a Leitz Orthoplan fluorescence microscope at $\times 1250$ magnification.
Rates of bacterial growth and net growth from changes in cell numbers. In 1994, bacterial numbers were determined for unfractionated and $<0.8 \mu \mathrm{m}$ fraction samples at both the beginning and the end of the oxygen flux incubations. Additional intermediate counts at intervals of $4 \mathrm{~h}$ were performed on Day 159 during the respiration time course experiment. For all incubations, subsamples for bacterial counts were taken from dark bottles. Daily growth rates $(\mu)$ were estimated using a linear ( $\mu=N_{t}-N_{0}$ ) growth model (Wright \& Coffin 1984) where $\left(N_{0}\right)$ and $\left(N_{t}\right)$ are the bacterial densities after 0 and $24 \mathrm{~h}$ respectively. For Days 130 and 159, daily growth rates were estimated by least-squares linear regression of bacterial density versus time.

Chlorophyll a. Subsamples (250 to $750 \mathrm{~cm}^{3}$ ) were filtered onto $47 \mathrm{~mm}$ Whatman $\mathrm{GF} / \mathrm{F}$ filters and the phytopigments extracted in $10 \mathrm{~cm}^{3}$ (1992) and $8 \mathrm{~cm}^{3}(1993$ and 1994) of neutralised $90 \%$ acetone solution for 24 to 48 h. In 1992 phytopigment concentrations were determined using a diode-array spectrophotometer (Hewlett-Packard, model 8452A) following the procedure of Parsons et al. (1984). During 1993 and 1994, phytopigment concentrations were estimated using a Turner 10 Designs fluorometer in accordance with the recommendations of Tett (1987).

Particulate organic carbon and nitrogen. Subsamples $\left(0.01\right.$ to $\left.1 \mathrm{dm}^{3}\right)$ were filtered onto $25 \mathrm{~mm}$ pre-combusted $\left(500^{\circ} \mathrm{C}\right.$ for $\left.3 \mathrm{~h}\right) \mathrm{GF} / \mathrm{F}$ filters. The filters were oven dried overnight at $40^{\circ} \mathrm{C}$ then wrapped in precombusted aluminium discs. The prepared filters were analysed using a Europa Scientific Robo-prep CN analyser attached to a tracermass stable isotope analyser.

Nitrate. The samples for nitrate concentration determination were processed immediately after collection according to the method of Parsons et al. (1984).

\section{RESULTS}

The water temperatures in both 1993 and 1994 were consistently higher than the 1992 values (Fig. 2A). This difference was particularly marked for the first sampling point in 1994 when the concurrent air temperature showed a decrease (Fig. 2B). A similar fall in air temperature also occurred at about the same time in 1993 (Fig. 2B).

\section{2 seasonal pattern}

The patterns for unfractionated chlorophyll a (chl a) (Fig. 3A) and gross community production (GCP, Fig. 3B) were similar, with 2 distinct peaks in the 

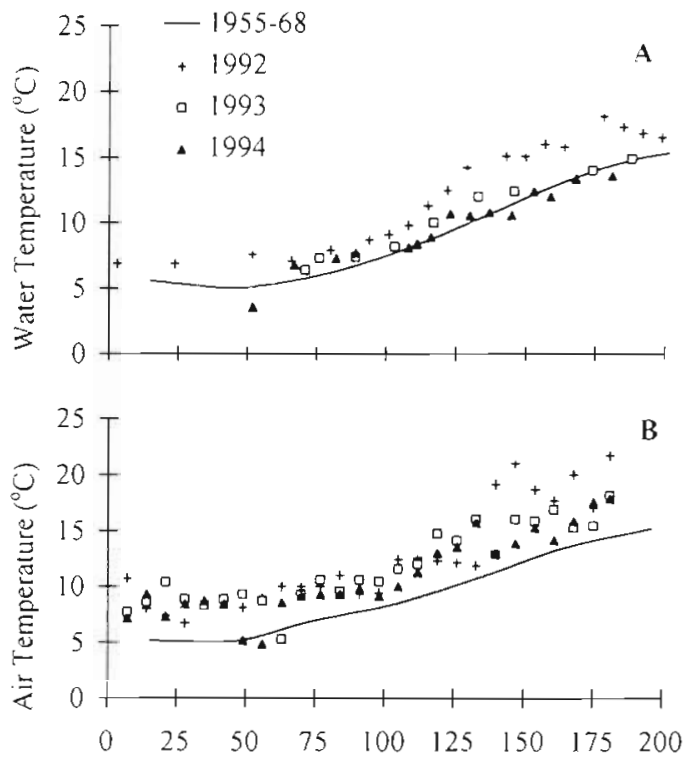

Fig. 2. Spring and early summer trends for (A) water temperature in the Menai Strait (North Wales, UK) and (B) air temperature at Valley (Anglesey, North Wales) during 1992, 1993 and 1994. The mean monthly temperatures for both parameters between the years 1955 and 1968 (Harvey 1972) are also shown for comparison

spring to early summer period. For both parameters the recorded annual maximum was on Day 128 . Unfractionated dark community respiration (DCR) was also characterized by 2 peaks (Fig. 3C) over the spring and early summer period, with the annual maximum (Day 142) recorded 2 wk after the chl a and GCP maximum. Net community production (NCP, Fig. 3D) exhibited 2 peaks in phase with those for chl $a$ and GCP. Its annual maximum (Day 128) was followed by a net heterotrophic phase lasting approximately $10 \mathrm{~d}$.

\section{3 seasonal pattern}

The $<200 \mu \mathrm{m}$ fraction chl a (Fig. 4A) and particulate organic carbon (POC, Fig. 4B) exhibited 2 peaks over the spring period. The first peak (diatomaceous) was recorded on Day 117. The second, constituting the annual maximum, was measured on Day 146 and was comprised predominantly of Phaeocystis cells. During the decline of this bloom the annual particulate organic nitrogen (PON) maximum was recorded (Day 160, Fig. 4B). Chl a concentrations then remained low, near $1 \mathrm{mg} \mathrm{m}^{-3}$, through July and August until a late summer diatom bloom (Guinardia flaccida, $3.4 \times$

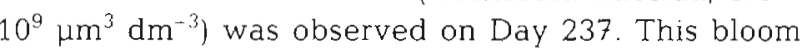
declined over the course of $2 \mathrm{wk}$ and chl a remained low, approximately $1 \mathrm{mg} \mathrm{m} \mathrm{m}^{-3}$, for the rest of the year. During the diatom blooms, the contribution of the
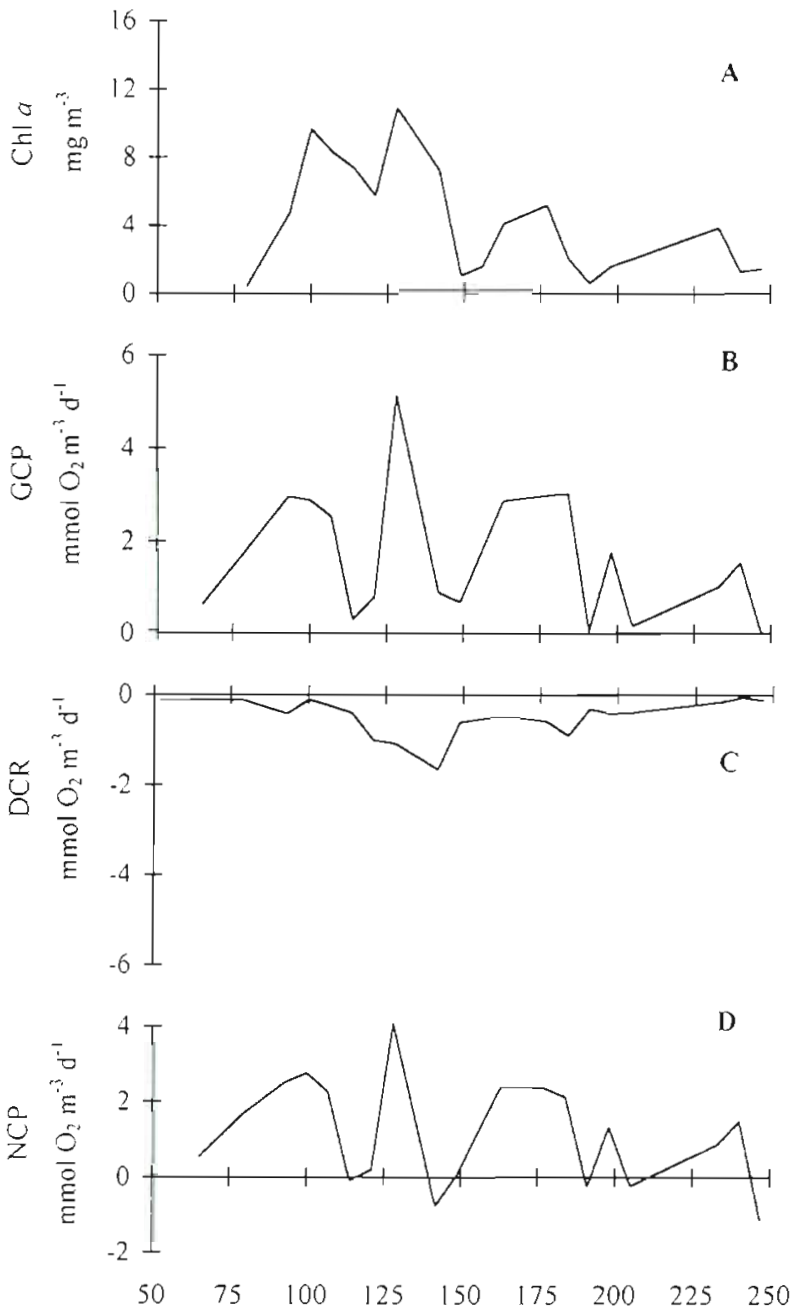

Day of Year 1992

Fig. 3. The 1992 seasonal patterns in the Menai Strait for the unfractionated plankton assemblage. Parameters shown are (A) chlorophyll a (chl a); (B) gross community $\mathrm{O}_{2}$ production (GCP); (C) dark community $\mathrm{O}_{2}$ respiration (DCR); and (D) net community $\mathrm{O}_{2}$ production (NCP)

$<20 \mu \mathrm{m}$ fraction of $\mathrm{chl}$ a relative to the $<200 \mu \mathrm{m}$ fraction was 20 to $25 \%$. During the Phaeocystis bloom, this contribution increased to approximately $50 \%$ and in July, when phytoplankton biomass was low, roughly $70 \%$ of the measured chl a was attributable to the $<20 \mu \mathrm{m}$ fraction.

The seasonal pattern of GCP and its size distribution was similar to that exhibited by the chl a concentration (Fig. 4C). The $<200 \mu \mathrm{m}$ fraction DCR rate was characterized by a smooth curve peaking on Day 160 (Fig. 4D). Maximal rates were exhibited for all size fractions (except for the $<0.8 \mu \mathrm{m}$ fraction) on Day 160. The respiration rate of the $<0.8 \mu \mathrm{m}$ size fraction appeared to peak a fortnight earlier (Day 146), when the $<0.8 \mu \mathrm{m}$ rate was significantly greater than the 

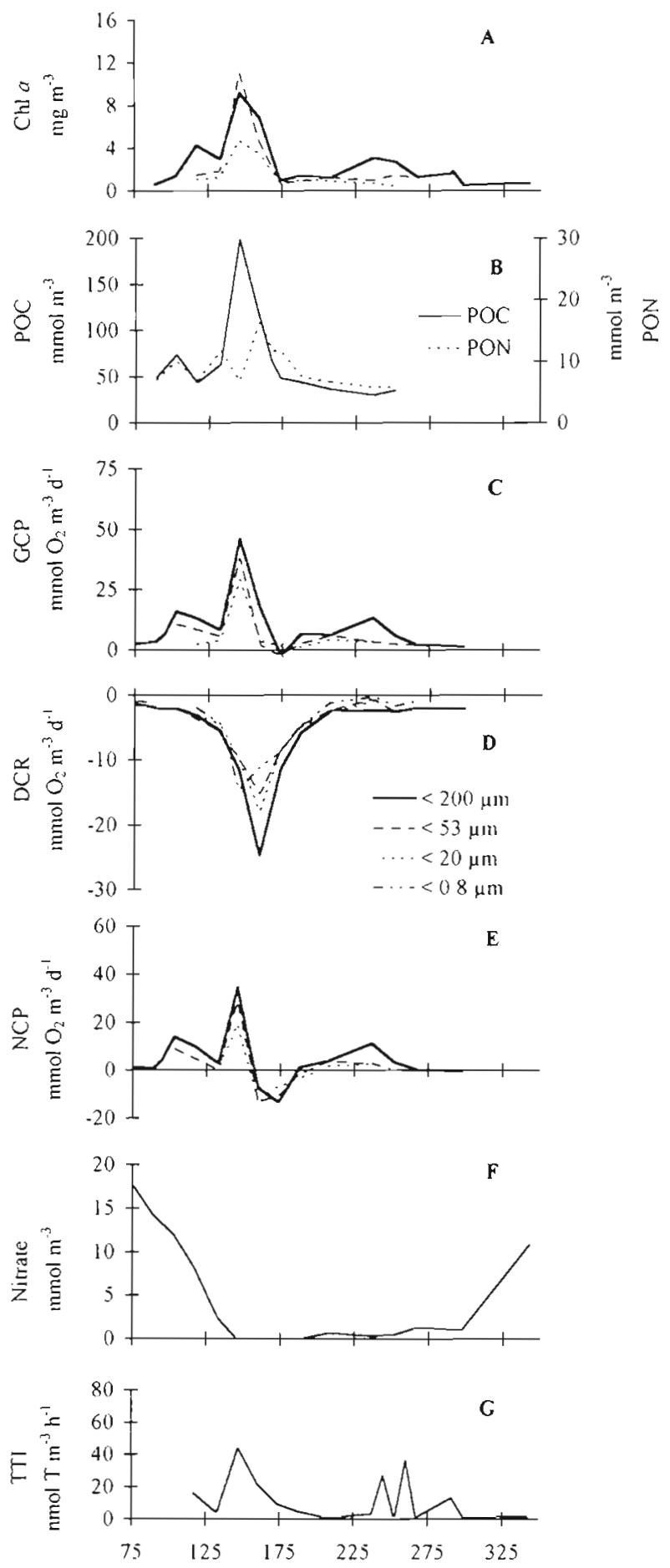

Day of Year 1993

Fig. 4. The 1993 seasonal patterns in the Menai Strait for the $<200 \mu \mathrm{m}$ fraction and where available the $<53,<20$ and $<0.8 \mu \mathrm{m}$ fractions. Parameters shown are (A) chlorophyll $a_{\text {; }}$ (B) particulate organic carbon (POC) and particulate organic nitrogen (PON); (C) gross community $\mathrm{O}_{2}$ production (GCP); (D) dark community $\mathrm{O}_{2}$ respiration (DCR); (E) net community $\mathrm{O}_{2}$ production (NCP); (F) nitrate concentration; and (G) tritiated thymidine incorporation (TTI) rate
$<200 \mu \mathrm{m}$ DCR rate (Student's sampled paired $t$-test, $\mathrm{p}<0.01, \mathrm{n}=3$ ). The $<0.8 \mu \mathrm{m}$ fraction on average accounted for $69 \%$ (range 28 to $131, \mathrm{n}=10$ ) of the $<200 \mu \mathrm{m}$ fraction DCR rate and this contribution was smallest on Day 178 . The $<200 \mu \mathrm{m}$ fraction net community production exhibited 3 peaks during the year (Fig. 4E). Each of these peaks coincided with a phytoplankton bloom. Following the Phaeocystis bloom, the net autotrophic community was succeeded by a net heterotrophic one, and this phase lasted for approximately 1 mo.

The nitrate concentration declined steadily prior to and during the spring diatom blooms periad (Fig. 4F). The Phaeocystis bloom reduced the nitrate concentration to below the limit of detection $(0.05 \mu \mathrm{M})$. Nitrate then remained low $(<1 \mu \mathrm{M})$ for approximately 4 mo before increasing again in late autumn. The tritiated thymidine incorporation rate exhibited a number of peaks over the course of the year, with the annual maximum occurring on Day 146 (Fig. 4G).

\section{4 spring bloom pattern}

The spring bloom was characterized by $3 \mathrm{chl}$ a peaks (Fig. 5A). The first peak was comprised of mixed diatoms (Day 116) with Asterionella glacialis and Ditylum brightwelli dominating numbers and biovolume respectively. These cells and most of the detritus largely disappeared from the water column by Day 123. The second chl a peak (Day 130) was again predominantly diatomaceous with Rhizosolenia delicatula $\left(3.5 \times 10^{5}\right.$ cells $\left.\mathrm{dm}^{-3}\right)$ as the major diatom, although Phaeocystis bladders (first observed on Day 129) were also present. The third peak occurred on Day 145 when $R$. delicatula $\left(4.5 \times 10^{5}\right.$ cells $\left.\mathrm{dm}^{-3}\right)$ was still abundant and the measured Phaeocystis maximum occurred (approximately $1 \times 10^{3}$ bladders $\mathrm{dm}^{-3}$ and $5 \times$ $10^{6}$ cells $\mathrm{dm}^{-3}$, Fig. 5B). The Phaeocystis cell counts had decreased dramatically by Day 159 , whereas high numbers of $R$. delicatula persisted until Day 168. Both $R$. delicatula and Phaeocystis bladders were absent from the water column by Day 181. Size fractionation of the chl a during the diatom blooms showed only $20 \%$ of the unfractionated chl a to reside in the $<20 \mu \mathrm{m}$ fraction. This contribution increased to $34-44 \%$ during the Phaeocystis-Rhizosolenia bloom and after the decline of this bloom increased to $87 \%$.

Three peaks in ciliate numbers and biovolume were observed over the phytoplankton blooms period (Fig. 5B, C). The first 2 of these coincided with the first $2 \mathrm{chl}$ a peaks. The third and largest ciliate peak occurred approximately $1 \mathrm{wk}$ after the Phaeocystis maximum when aloricate choreotrichs approximately $20 \mu \mathrm{m}$ in diameter predominated. Dinoflagellates (pre- 

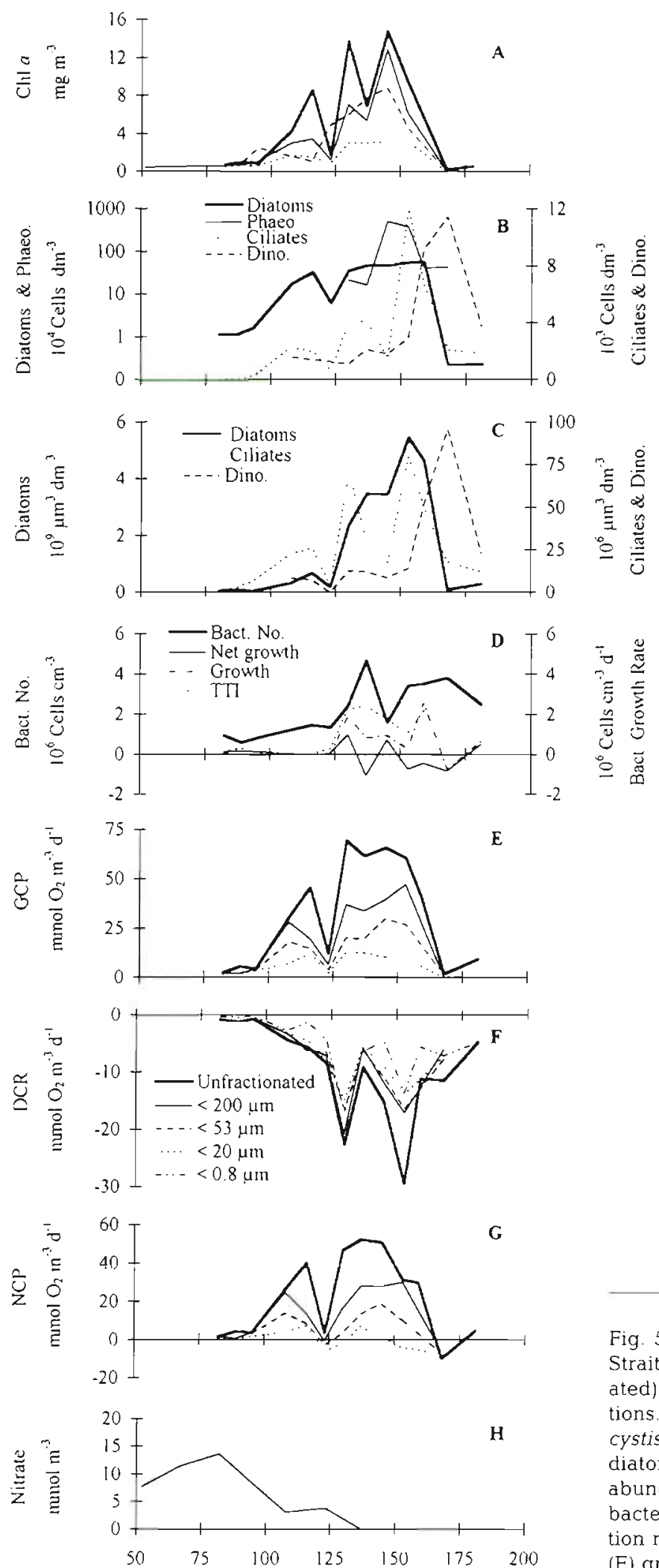

Day of Year 1994 dominantly Gyrodinium spp.) also increased during the decline of the Phaeocystis with the maximal abundance and biovolume occurring on Day 169 (Fig. 5B, C). Mesozooplankton were not effectively sampled in this study, but their larvae were present in the sample bottles in small numbers (maximal abundance very approximately 100 larvae $\mathrm{dm}^{-3}$ )

Bacteria numbers showed a gradual increase from $3 \times 10^{5}$ cells $\mathrm{cm}^{-3}$ on Day 52 to $4.5 \times 10^{6}$ cells $\mathrm{cm}^{-3}$ on Day 137 (Fig. 5D). A second more protracted peak $\left(>3 \times 10^{6}\right.$ cells $\left.\mathrm{cm}^{-3}\right)$ occurred between Days 153 and 168 and numbers then declined to $1.5-2 \times 10^{6}$ cells $\mathrm{cm}^{-3}$. On average $61 \%$ (45 to $92 \%$, $\mathrm{n}=14$ ) of the unfractionated bacterioplankton assemblage was isolated in the $<0.8 \mu \mathrm{m}$ fraction and this fraction had no significant eucaryote abundances. Although bacterial cell sizing was not undertaken, those that were sized were mostly 0.4 to $0.5 \mu \mathrm{m}$ diameter cocci.

The thymidine conversion factor experiment yielded a factor of $2.76 \times 10^{18} \mathrm{cells}^{-1} \mathrm{~mol}^{-1}$, which lies within the range reported in the literature (median $2 \times 10^{18}$, range $1 \times 10^{17}$ to $60 \times 10^{18}$ cells $\mathrm{mol}^{-1}$; Ducklow \& Carlson 1992). Using this factor the estimates of growth from TTI and changes in cell numbers in the $<0.8 \mu \mathrm{m}$ fraction were similar, with no significant growth before Day 130 (Fig. 5D). The estimates of net growth, from changes in cell numbers in the unfractionated sample, similarly showed no significant net growth before Day 130 (Fig. 5D). There were 2 peaks in positive net growth, Days 130 and 145, and 2 periods of negative net growth, Day 137 and Days 153 to 168.

Unfractionated GCP followed the same trend as the chl a concentration although the second 2 peaks were less well defined (Fig. 5E). Size fractionation showed that during the mixed diatom and Rhizosolenia delicatula blooms, approximately $20 \%$ of the unfractionated GCP was accounted for by the $<20 \mu \mathrm{m}$ fraction. This percentage contribution continued to remain low, at 16 to $20 \%$ of the unfraction-

Fig. 5. The 1994 spring and early summer patterns in the Menai Strait for the unfractionated plankton assemblage (Unfractionated), and where available, the $<200,<53,<20$, and $<0.8 \mu \mathrm{m}$ fractions. Parameters shown are (A) chlorophyll $a_{i}$ (B) diatom, Phaeocystis (Phaeo.), ciliate and dinoflagellate (dino.) cell counts; (C) diatom, ciliate and dinoflagellate (dino.) biovolumes; (D) bacterial abundance (Bact. No.), bacterial net growth rate (Net growth), bacterial growth rate (Growth), and tritiated thymidine incorporation rate (TTl) using a conversion factor of $2.76 \times 10^{18} \mathrm{cells} \mathrm{mol}^{-1}$; (E) gross community $\mathrm{O}_{2}$ production (GCP); (F) dark community $\mathrm{O}_{2}$ respiration (DCR); (G) net community $\mathrm{O}_{2}$ production (NCP); and $(\mathrm{H})$ nitrate concentration 
ated value, during the Phaeocystis-Rhizosolenia bloom. Two peaks were observed in DCR (Fig. 5F) over the spring period. Respiration was largely attributable to the smallest size fractions. The $<0.8 \mu \mathrm{m}$ fraction on average accounted for $49 \%$ (range 21 to $101 \%, n=13$ ) of unfractionated DCR. This contribution was highest $(>70 \%)$ during the early phases of the Rhizosolenia and the Phaeocystis blooms. Unfractionated NCP exhibited 2 peaks (Fig. 5G). The second of these, the Phaeocystis-Rhizosolenia bloom, was succeeded by a net heterotrophic phase lasting approximately $12 \mathrm{~d}$.

A 2 phase decrease in nitrate concentration was observed (Fig. 5H). The second, smaller phase (Days 123 to 137), coincided with the rise of the Phaeocystis bloom. This bloom reduced the nitrate concentration to below the limit of detection.

An area budget for NCP over the bloom period was estimated for a representative $1 \mathrm{~m}^{2}$ cross-section of the Menai Strait, North Wales. Secchi disc depths were used to estimate $k_{\mathrm{d}}$, and assumptions made that GCP was proportional to light and DCR constant with depth. NCP for the cross-section equals the numerically integrated GCP minus the integrated DCR. This value was divided by the cross-sectional width to derive the average NCP per unit area (Fig. 6).

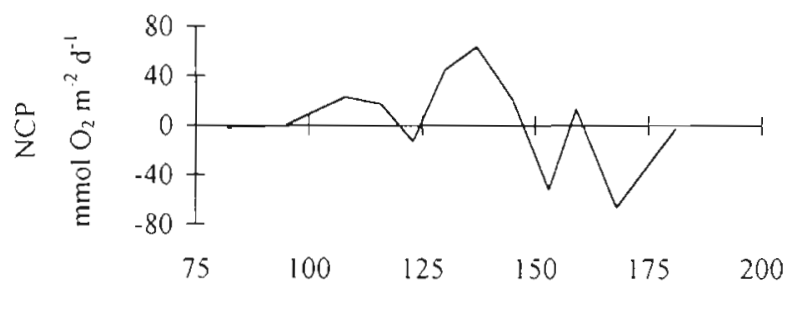

Day of Year 1994

Fig. 6. Area net community $\mathrm{O}_{2}$ production for the spring blooms period in the Menai Strait in 1994

\section{Time course experiments of respiration}

Time course experiments were undertaken to determine if major artifacts occurred in the $<0.8 \mu \mathrm{m}$ fraction due to removal of predator pressure. Respiration was linear with time during the 2 separate experiments. Bacterial counts were measured during the second time course experiment (Day 160 of 1994, Fig. 7). These showed no obvious increase in bacterial abundance in the unfractionated sample, but a marked increase in abundance in the $<0.8 \mu \mathrm{m}$ fraction.

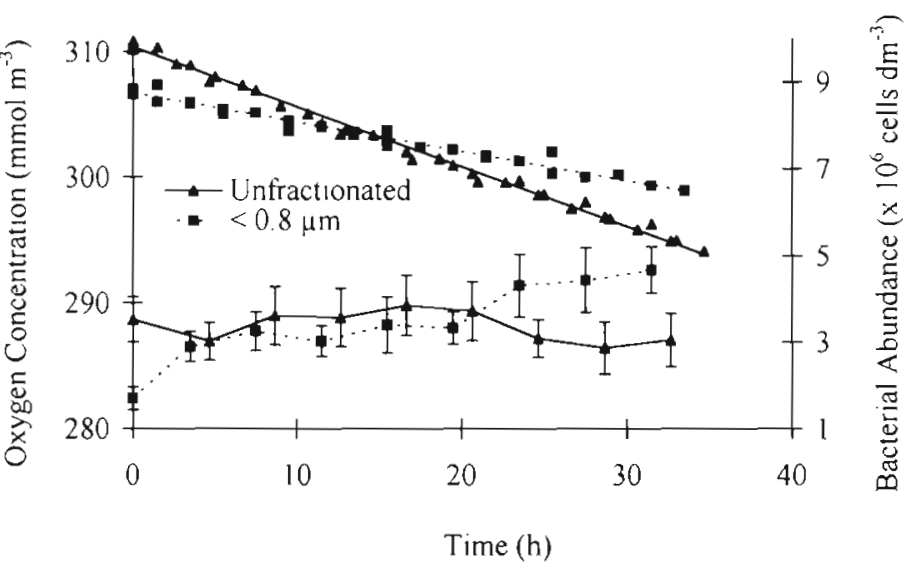

Fig. 7. Oxygen concentrations and bacterial abundances during the time course experiment for dark community respiration on Day 153 in 1994. Upper curves show the least squares linear regressions for the oxygen replicates; lower curves show the bacterial abundances $\pm 1 \mathrm{SD}$

\section{DISCUSSION}

The Menai Strait is a shallow turbulent stretch of water separating the island of Anglesey from the mainland of North Wales. The estimated magnitude and direction of residual flow (Harvey 1968) suggest that plankton sampled from Menai Bridge largely originates from the adjacent coastal waters of Liverpool Bay, with the advected plankton residing in the Strait for approximately $2 \mathrm{~d}$. A density discontinuity isolates Liverpool Bay and fluvial inputs lead to nutrient buildup during winter months (Foster et al. 1982). The nitrate concentrations measured in the present study compare well with previous observations (Ewins \& Spencer 1967).

The general patterns of chl a concentrations during the spring bloom periods of the $3 \mathrm{yr}$ of this study conformed to the succession typical for the area: a mixed diatom bloom in March and April followed by blooms of diatoms and Phaeocystis in May and June (Jones \& Haq 1963, Jones \& Spencer 1970, Al-Hasan et al. 1975). For each of these years, the annual chl a maximum coincided with the presence of Phaeocystis in the Strait.

In 1994, the measurement of chl a was supplemented with phytoplankton and microheterotroph cell counts and biovolume estimates. These measurements are difficult to make without error: the cell abundances estimated by the inverted technique are probably underestimates because of incomplete settling and shielding by detritus. Furthermore, there is now evidence that the interpretation of the standard DAPI count for bacteria is not straightforward (Suzuki et al. 1993, Zweifel \& Hagström 1995). 
During the first chl a maximum (Days 116 to 123), the contribution of small colonial diatoms to total diatom numbers was greater than $80 \%$. Previous studies in the Strait have also recorded these small diatoms, especially Skeletonema costatum, to predominate in the early spring period. These diatoms possess high surface area: volume ratios and maximal growth rates and characterize the first stage of the typical succession (Margalef 1958). However, the biovolume contribution of these small diatoms was only $40 \%$, with the larger diatom Ditylum brightwelli accounting for a further 35 to $40 \%$. The $D$. brightwelli, the small diatoms and the obvious detrital loading largely disappeared from the water column over the course of a week (Days 123 to 130), suggesting advection or sinking losses to be important. This is consistent with previous studies of coastal diatom blooms (Kiørboe 1993).

The second chl a maximum (Day 130) corresponded to a Rhizosolenia delicatula (a medium-sized stage 2 diatom; Margalef 1958) bloom in its mid-late exponential phase. The increases in bacterioplankton and ciliate numbers associated with this exponential phase is in keeping with a very close coupling between the autotrophs and microheterotrophs. This Rhizosolenia bloom persisted for a further $30 \mathrm{~d}$, overlapping with the Phaeocystis bloom that reached its maximum abundance on Day 145, the day of the third chl a maximum. The morphology of unfixed bladders best fitted Phaeocystis globosa characteristics as described by Baumann et al. (1994), and the maximum Phaeocystis cell count of approximately $5 \times 10^{6}$ cells $\mathrm{dm}^{-3}$ falls at the lower end of the range previously recorded for the Strait (1.4 to $100 \times 10^{6}$ cells $\mathrm{dm}^{-3}$; Jones 1968 , Tyler 1977 , Lennox 1979). For this bloom, the autotroph-heterotroph coupling appeared looser, with a delay of approximately 1 wk between the Phaeocystis maximum and the following bacterioplankton and ciliate increase; similar delays have been documented for Phaeocystis blooms in the coastal waters of the German Bight (Laanbroek et al. 1985, Billen \& Fontigny 1987, van Boekel et al. 1992). The dinoflagellate assemblage also exhibited a distinct maximum (Day 168) after the Phaeocystis bloom when chl $a$ and gross community production were very low, suggesting this assemblage to have an important heterotrophic component. The spring bloom succession finished with an autotroph assemblage dominated in numbers by small cryptophytes.

After the spring blooms in 1992 and 1993, phytoplankton biomass remained low, with intermittent small, probably diatomaceous blooms, in agreement with previous observations in the Strait (Jones " \& Spencer 1970). The 1993 late summer diatom bloom was essentially monospecific; this is also in accordance with Jones \& Spencer (1970). In Liverpool Bay, the breakdown of the density discontinuity in late summer or early autumn influenced the timing of later diatom blooms (Voltalina et al. 1986) and blooms in the Strait may be similarly influenced.

The main mixed Phaeocystis and diatom bloom in 1992 occurred approximately 20 d earlier than in 1993 and 1994. Similar variability was observed previously in the Strait by Jones \& Haq (1963), who suggested that water temperature in early spring influenced the timing of the bloom. Our limited observations of water temperature and air temperature readings offer support for this contention; although other factors such as detrital loading (Jones \& Spencer 1970) may also be important.

The general patterns and scales of GCP are similar for all 3 yr and are in broad agreement with previous ${ }^{14} \mathrm{C}$ studies in the Menai Strait (Al-Hasan 1976, Bajpai 1980). They are also comparable to those reported for Liverpool Bay in the spring (4 to $141 \mathrm{mmol} \mathrm{C} \mathrm{m} \mathrm{Cd}^{-1}$; Savidge \& Kain 1990). Respiration has not been measured previously in the area, but our measurements are comparable to those reported during the spring bloom period in the German Bight (Laanbroek et al. 1985)

The correlation analysis showed DCR to be highly correlated to GCP and not significantly related to temperature (Table 1). This contrasts with temperate estuarine studies that usually report a better correlation between DCR and temperature (e.g. Smith \& Kemp 1995) and is consistent with an ecosystem whose pelagic metabolism is based on phytoplankton production rather than allochthonous inputs (Hopkinson 1985). However, temperature was the best predictor for chl a-specific GCP in accordance with previous observations in the Strait and other temperate waters (Fogg \& Bajpai 1988). Harrison (1986) reported that chl a-specific GCP increases with decreasing cell size. Our size fractionation data for 1994 (Fig. 8) generally does not show this relationship and so a shift in the size structure of the phytoplankton community towards smaller forms cannot account for the correlation with temperature; this agrees with Fogg \& Bajpai (1988). These authors discussed other possible explanations, including shade adaptation and ribulose bisphosphate carboxylase (RUBISCO) activation.

There is a potential error involved in measurement of size fractionated metabolism due to the increase of fast growing organisms as a result of the removal of predators. With this in mind, we undertook time course measurements of DCR. During the time course experiment for DCR on Day 159 the increase in bacterial numbers was not accompanied by an increase in DCR; this is in accordance with the observations of Pomeroy et al. (1994). Although size fractionation is reported as sometimes producing enhanced respiration rates (e.g. Hopkinson et al. 1989), the only data point in our stud- 
Table 1. Correlation coefficients between temperature, chlorophyll $a$, bacterial abundance, ciliate abundance, gross community production (GCP), dark community respiration (DCR), tritiated thymidine incorporation rate (TTI), <0.8 $\mu$ m fraction respiration rate $\left(<0.8 \mu \mathrm{m}\right.$ DCR), bacterial cell-specific tritiated thymidine incorporation rate (TTI cell $\left.{ }^{-1}\right),<0.8 \mu \mathrm{m}$ fraction cell-specific respiration rate $\left(<0.8 \mu \mathrm{m} \mathrm{DCR} \mathrm{cell}{ }^{-1}\right)$, and chlorophyll a-specific gross community production (GCP chl $a^{-1}$ ) for the Menai Strait in 1994 (n=13). Significant at $p<0.05, \cdots p>0.01, \cdots p<0.001$

\begin{tabular}{|c|c|c|c|c|c|c|c|c|c|c|c|}
\hline & Temp. & Chl a & $\begin{array}{l}\text { Bacteria } \\
\text { numbers }\end{array}$ & $\begin{array}{c}\text { Ciliate } \\
\text { numbers }\end{array}$ & $\mathrm{GCP}$ & DCR & TTI & $\begin{array}{l}<0.8 \mu \mathrm{m} \\
\mathrm{DCR}\end{array}$ & $\begin{array}{c}\text { TTI } \\
\text { cell }^{-1}\end{array}$ & $\begin{array}{c}<0.8 \mu \mathrm{m} \\
\text { DCR cell }\end{array}$ & $\begin{array}{c}\text { GCP } \\
\text { chl } a^{-1}\end{array}$ \\
\hline Temperature & - & 0.04 & $0.73 \cdots$ & 0.47 & 0.11 & 0.51 & $0.67^{\circ}$ & $0.67^{\circ}$ & 0.40 & 0.32 & $0.65^{\circ}$ \\
\hline Chlorophyll a & & - & 0.21 & 0.45 & $0.95 \cdots$ & $0.70^{\circ}$ & $0.72^{\circ}$ & 0.51 & $0.71^{\circ}$ & $0.62^{\bullet}$ & -0.34 \\
\hline Bacteria numbers & & & - & $0.64^{*}$ & 0.42 & $0.53^{\circ}$ & $0.78 \cdots$ & $0.71^{\bullet}$ & 0.30 & $0.71^{\cdots}$ & 0.41 \\
\hline Ciliate numbers & & & & - & $0.59^{\circ}$ & $0.81^{\cdots}$ & 0.44 & $0.82 \cdots$ & 0.12 & 0.41 & 0.05 \\
\hline $\mathrm{GCP}$ & & & & & - & $0.72 \cdots$ & $0.75^{\circ}$ & $0.60^{\circ}$ & $0.60^{\circ}$ & $0.61^{\circ}$ & -0.21 \\
\hline DCR & & & & & & - & 0.56 & $0.94 \cdots$ & 0.47 & $0.71^{\cdots}$ & -0.10 \\
\hline TTI & & & & & & & - & $0.61^{\circ}$ & $0.80^{*} \cdot$ & 0.49 & 0.28 \\
\hline$<0.8 \mu \mathrm{m} \mathrm{DCR}$ & & & & & & & & - & 0.40 & $0.69 \cdots$ & 0.16 \\
\hline TTI cell ${ }^{-1}$ & & & & & & & & & - & 0.51 & -0.14 \\
\hline$<0.8 \mu \mathrm{m} \mathrm{DCR}$ cell $^{-}$ & & & & & & & & & & - & 0.07 \\
\hline GCP chl $a^{-1}$ & & & & & & & & & & & - \\
\hline
\end{tabular}

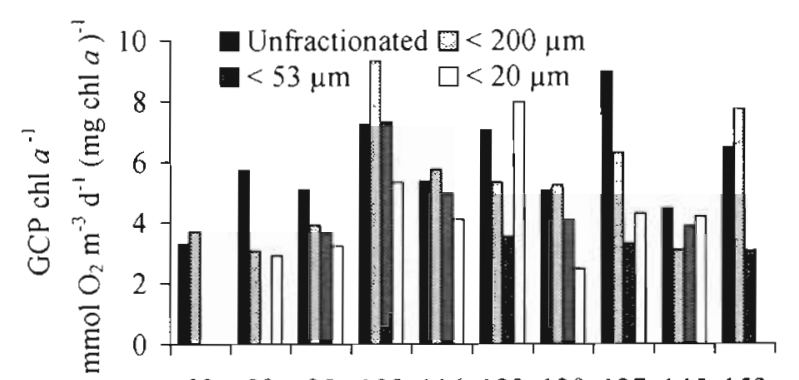

$\begin{array}{llllllllll}82 & 89 & 95 & 108 & 116 & 123 & 130 & 137 & 145 & 153\end{array}$

Day of Year 1994

Fig. 8. Chlorophyll a-specific gross community $\mathrm{O}_{2}$ production (GCP chl $a^{-1}$ ) during the spring blooms period in the Menai Strait in 1994 for the unfractionated plankton assemblage

(Unfractionated), and $<200,<53$ and $<20 \mu \mathrm{m}$ fractions

ies consistent with such an effect is the Day 146 sampling of 1993. We used a cross-flow filtration system for the first time for the preparation of this sample and are inclined to attribute the anomalous result to our inexperience with this technique.

During the spring bloom period of 1994, the fractionations revealed micro- and mesophytoplankton to dominate autotroph production and biomass, which is typical for temperate coastal spring blooms (Kiørboe 1993). However, although the nanophytoplankton contribution to total GCP during this bloom period was small $(20 \%)$, respiration by the organisms in this size range was substantial, accounting for approximately $70 \%$ of the total DCR. This differential effect of size fractionation on GCP and DCR has been reported previously for diatom bloom communities (e.g. Williams 1981, Harrison 1986, Smith et al. 1986). The results of the $0.8 \mu \mathrm{m}$ fractionations showed this effect to be largely attributable to the activity of the bacterioplank- ton in accordance with earlier studies (Williams 1981, Harrison 1986).

We have combined the $<0.8 \mu$ m fraction DCR and the DAPI bacterial counts in order to estimate the cellspecific respiration rates (Fig. 9A). There are clearly uncertainties to these calculations - the DAPI count may potentially grossly overestimate the number of metabolically active cells (Zweifel \& Hagström 1995), thus the rate may be proportionately underestimated. The range $\left(0.4\right.$ to $6.8 \mathrm{fmol} \mathrm{O}_{2}$ cell $\left.^{-1} \mathrm{~d}^{-1}\right)$ is similar to that
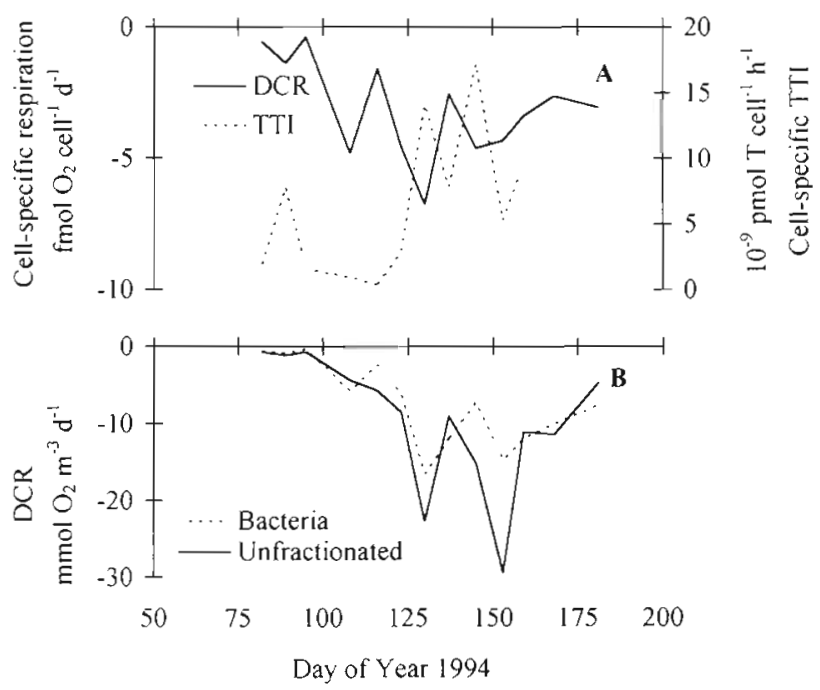

Fig. 9. Bacterioplankton metabolism during the spring blooms period in the Menai Strait in 1994. Showing (A) cell-specific respiration (DCR) and tritiated thymidine incorporation (TTI) rates, and $(B)$ the bacterial contribution (bacteria) to unfractionated plankton assemblage (Unfractionated) respiration. This contribution is estimated by dividing the $<0.8 \mu \mathrm{m}$ fraction respiration rate by the fraction of the unfractionated bacterial assemblage isolated in the $<0.8 \mu \mathrm{m}$ fraction 
estimated by Biddanda et al. (1994) for the $<1 \mu \mathrm{m}$ fraction in Louisiana (USA) shelf waters: 2.4 to $8.7 \mathrm{fmol}_{2}$ cell $\mathrm{d}^{-1} \mathrm{~d}^{-1}$

The 3 distinct peaks in the cell-specific respiration rates, coincident with the 3 phytoplankton blooms (Fig. 9A), are consistent with a very close coupling between bacterial cell respiration and phytoplankton production and biomass. The bacterial cell specific TTI rates showed a similar trend (Fig. 9A). As the percentage of the total bacterioplankton assemblage isolated in the $<0.8 \mu \mathrm{m}$ fraction varied considerably, multiplication of the cell-specific respiration rates by the total bacterial abundance gives a better assessment of the bacterial contribution to unfractionated DCR (Fig. 9B). This shows the dominant contribution of the bacteria to unfractionated metabolism, but also identifies 4 sampling points (Days 116, 130, 145 and 153) as having substantial non-bacterial components. The Days 116 , 130 and 145 correspond to the $3 \mathrm{chl}$ a maxima, suggesting that autotroph dark respiration may have been significant. This is in agreement with previous studies (e.g. Iriarte et al. 1991). The sampling point on Day 153 corresponds to the distinct maximum in ciliate abundance concomitant with the declining Phaeocystis, which suggests that these microheterotrophs may be significant respirers. However, an upper limit on the ciliate respiration contribution for Day 153 can be estimated from the ciliate respiration rates reported in Fenchel \& Finlay (1983). This suggests ciliates could have accounted for a maximum of $25 \%$ of the nonbacterial respiration. Other major microhetereotrophic respirers may have included nano- and picoflagellates, a group that unfortunately were not enumerated in this study, and mesozooplankton larvae. The biomass and metabolism parameters for the $<53 \mu \mathrm{m}$ fraction (Fig. 10) also show that an increase in the dark respiration of Phaeocystis cannot be excluded. Indeed Phaeocystis cells face new energetic demands during the blooms' senescent phase, e.g. flagella synthesis (Rousseau et al. 1994), and the reassimilation of colonial matrix components (Lancelot \& Mathot 1985,

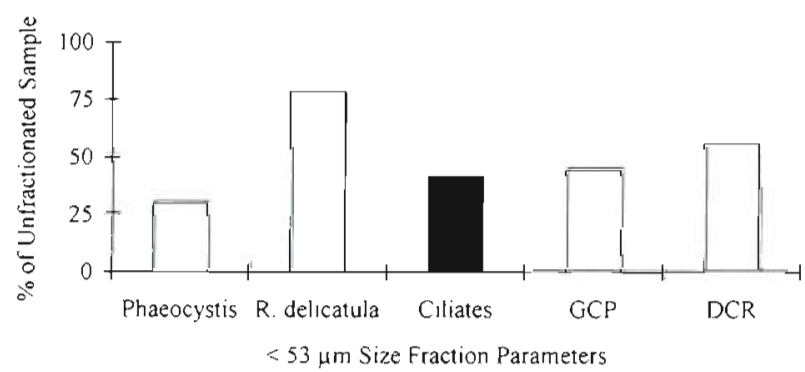

Fig. 10. Parameters for the $<53 \mu \mathrm{m}$ fraction on Day 153 of 1994 as percentages of the unfractionated plankton assemblage parameters
Veldhuis \& Admiraal 1985) may be able to support increased respiration as photosynthesis declines.

Correlation analysis of the 1994 data set (Table 1) showed ciliate abundance to be the best biomassrelated predictor of unfractionated DCR. However, because we did not enumerate nano- and picoflagellates, we cannot rule out the possibility that the ciliates were simply a proxy for these protozoans. The analysis also showed the TTI and $<0.8 \mu \mathrm{m}$ fraction respiration rates to be correlated with temperature, and more closely correlated with GCP and chl a than bacterial abundance. Analysis of bacterial cell-specific metabolic rates (TTI cell ${ }^{-1}$ and $<0.8 \mu \mathrm{m} \mathrm{DCR} \mathrm{cell}{ }^{-1}$ ) revealed significant correlations with GCP and chl $a$, but no close relationship with temperature. This indicates that biological parameters (e.g. substrate quality and quantity) limit bacterial metabolism rather than temperature, contrasting with the observations of Shiah \& Ducklow $(1994 \mathrm{a}, \mathrm{b})$ for non-summer conditions in a temperate estuary.

The phasing of GCP and DCR can be considered by plotting the 2 parameters against one another, as in Fig. 11. The separation of GCP and DCR maxima in time for the Phaeocystis bloom is similar to the pattern observed in space for an autotroph-heterotroph succession along a river length (Odum 1956). In our study, the phasing of GCP and DCR consisted of periods of positive production relaxing into negative production, a temporal succession similar to the longitudinal (i.e. time-dependent) succession reported for the Peruvian upwelling zone (Vinogradov \& Shushkina 1978). Simple calculations of volume-based rates of NCP are misleading because of the difference in the depth distribution of GCP and NCP in mixed water. Areanormalised rates are more meaningful. Our estimates of area NCP (using Secchi depths to estimate $k_{\mathrm{d}}$ ) integrated for the bloom period in 1994 suggest that metabolism within the water column approximately balanced. Although use of the Secchi depth to estimate $k_{\mathrm{d}}$ is not ideal (Kirk 1994), previous work in the Strait has shown this depth is well correlated with $k_{d}$ (D. Bowers pers. comm.). The phasing of GCP and DCR for the diatom blooms was different from that for Phaeocystis, i.e. the absence of an obvious DCR maxima in association with the mixed diatom blooms, and the distinct DCR maxima in phase with the rise of the Rhizosolenia delicatula in 1994

The aim of this study was to address the basis of this phasing and to consider the mechanisms involved. We have identified heterotrophic bacterioplankton as major respirers; thus the time scales of the different routes by which autotroph organic matter becomes available to the bacterioplankton are critical in explaining the phasing of GCP and DCR over the bloom periods. We now consider these routes in an 


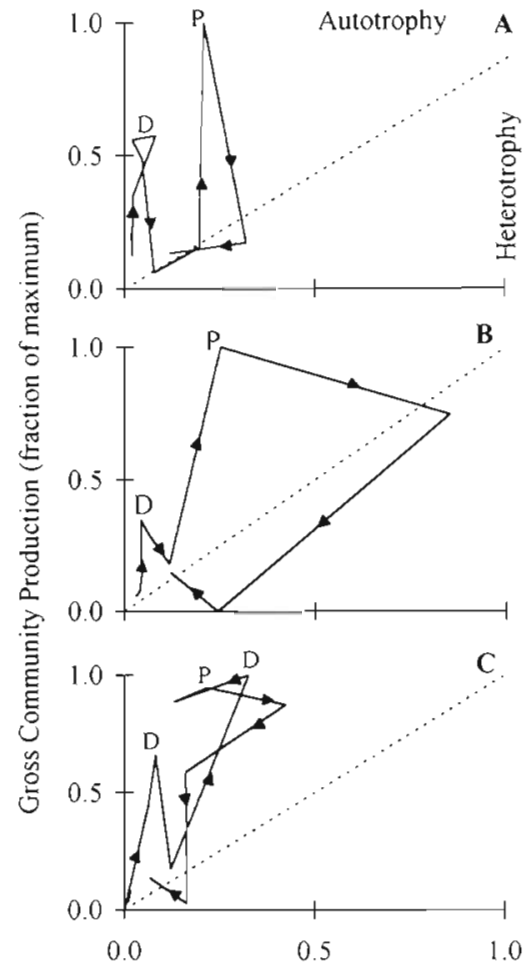

Respiration (fraction of GCP maximum)

Fig. 11. Phase plots of photosynthesis versus respiration in the Menai Strait for (A) 1992, (B) 1993 and (C) 1994. Arrows indicate the temporal sequence, $\mathrm{D}$ denotes a diatom maximum, and $\mathrm{P}$ denotes a Phaeocystis maximum

effort to explain the different DCR responses for the 3 bloom types: the mixed diatom blooms, the Rhizosolenia delicatula bloom, and the Phaeocystis blooms.
There are a number of possible pathways of organic matter transfer between phytoplankton and bacterioplankton. The following section is an attempt to ascribe broad time scales (e.g. $1 \mathrm{~d}, 1 \mathrm{wk}, 1 \mathrm{mo}$ ) to these various steps, using data, where possible, from similar ecosystems and similar times of the year. The principal routes linking microbial photosynthetic and respiratory activity are shown in a simplified diagram (Fig. 12). The key assumptions in this scheme are as follows:

(1) Phytoplankton exudation is closely associated with photosynthesis and biomass and largely produces LMW material (Bjornsen 1988) (Pathway I).

(2) The pool of LMW material is readily assimilable by bacteria and is turned over on a time scale of $\leq 1 \mathrm{~d}$ (e.g. Fuhrman 1987) (Pathway II).

(3) LMW material constitutes a small amount of the total organic material present in a phytoplankton cell (e.g. Smith \& Geider 1985), so cell lysis (self or viral) and breakage (sloppy feeding) largely introduce high molecular weight (HMW) material into the water column (Pathway III).

(4) The HMW material arising from these sources must be hydrolysed by ectoenzymes before it can be assimilated by the bacterioplankton (Chróst 1990a). The derepression and induction of these enzymes is a rapid process ( $<1$ d, Chróst 1990b), and their activity results in the HMW pool turning over every few days to a week (e.g. Billen 1990) (Pathway IV).

(5) Nano- and microzooplankton maximal generation times ( $<1$ d) are similar to those of the phytoplankton and their potential grazing activity is proportional to their biomass. A significant fraction of their organic intake is egested concurrently, with the assimilation
Fig. 12. Pathways linking gross community production (GCP) and dark community respiration (DCR) within a microbial foodweb. LMW: low molecular weight organic matter; HMW: high molecular weight organic matter; I: phytoplankton exudation; II: bacterial uptake; III: phytoplankton lysis; IV: ectoenzyme catalysed hydrolysis; V: microzooplankton grazing; VI: mesozooplankton grazing; VIIa: phytoplankton sedimentation; VIIb: detritus resuspension; VIII: release of hydrolysate derived from epiphytic bacterial activity. Numbers in parentheses indicate secondary pathways. Values in parentheses within the boxes are estimates of (biomass) doubling times

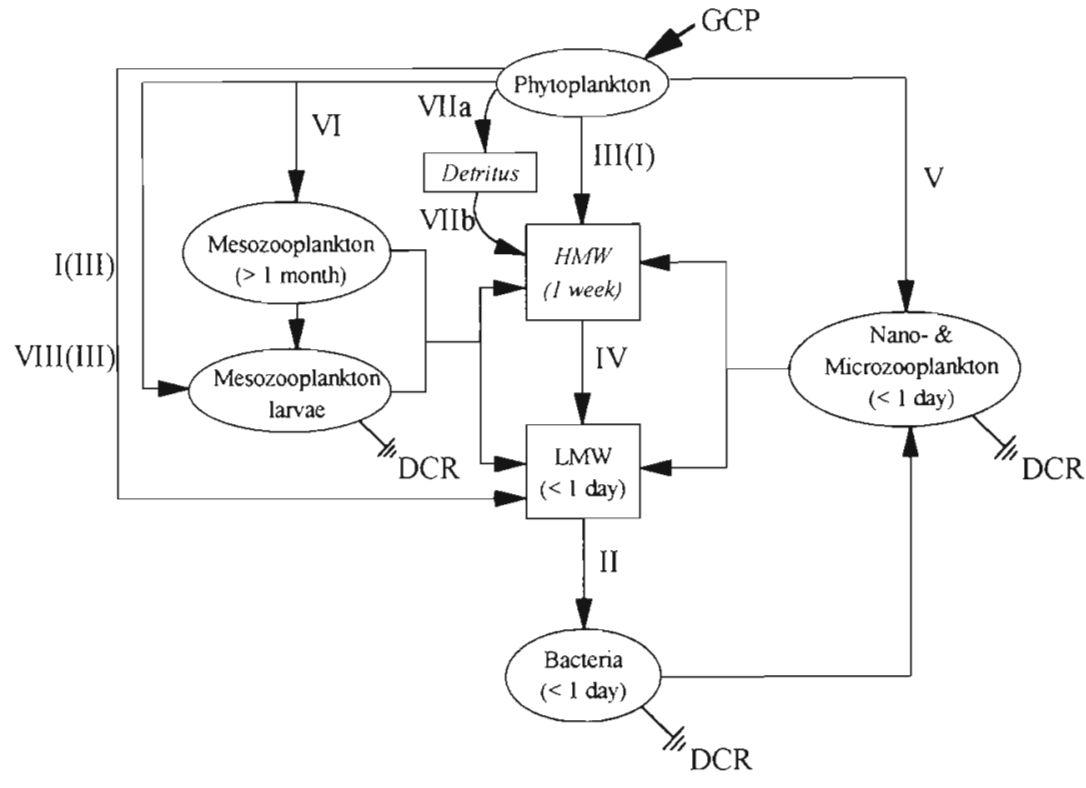


efficiency inversely proportional to grazing rate (Nagata \& Kirchman 1992) (Pathway V).

(6) Mesozooplankton generation times ( $\geq 1$ mo, e.g. Klein Breteler et al. 1982) are much longer than those of the nano- and microzooplankton, so they show no numerical response during a phytoplankton bloom; however, their larvae can exhibit abundance pulses during a bloom. Mesozooplankton potential grazing activity is proportional to their biomass and a significant proportion of their organic intake is egested and excreted concurrently (Jumars et al. 1989, Kiørboe 1993) (Pathway VI).

For the first bloom type, the mixed diatom blooms, an increase in bacterial cell-specific respiration was observed in phase with GCP in 1994, but low bacterial biomass meant this was not paralleled by an obvious unfractionated sample DCR response. Bacterial growth rate estimates (TTI and changes in cell numbers over $24 \mathrm{~h}$ ) also indicated low bacterial activity. These observations suggest that the passage of organic matter from the diatoms to the bacterioplankton was minimal and only sufficient for maintenance of the bacterioplankton community; although the substrate concentration required for bacterial cell growth may have been higher during this phytoplankton bloom than during the following ones because of the lower water temperature (Wiebe et al. 1993). Given the high GCP during the bloom, it is evident that much of the production was lost elsewhere. If mesozooplankton grazing was the predominant loss factor, we would expect (see point 6) that the flux of organic matter to the bacterioplankton should have been more substantial. By elimination this suggests physical losses (e.g. pathway VIIa, phytoplankton sedimentation, with no significant immediate resuspension) most likely predominated, which is in agreement with previous studies for coastal spring diatom blooms (Kiørboe 1993).

The second bloom type, the exponential phase of the Rhizosolenia delicatula bloom (e.g. ca Day 130), was characterized by a large concurrent increase in bacterial cell-specific respiration and growth rates, increasing bacterial abundance and a distinct ciliate biovolume maximum. Community bacterial growth rate estimates (TTI and changes in cell numbers over $24 \mathrm{~h}$ ) also indicated high bacterial activity and net growth. The bacterial abundance maximum was observed the following week (Day 137) when both cell-specific respiration and growth rates had decreased. Consideration of the most probable pathways of organic matter transfer to the bacteria, given this very close coupling, suggests the main routes to be phytoplankton exudation (I) and the LMW forks of the grazing pathways (V and VI). Significant flux to the bacterioplankton via phytoplankton exudation during the exponential growth phase of phytoplankton blooms has been reported previously (e.g. Chróst 1990b) Indeed, flux through the phytoplankton exudation pathway, whether this pathway is an overflow response (Fogg 1983), or a passive loss process (Bjørnsen 1988), would be more substantial during this bloom than during the earlier mixed diatom bloom.

Finally, the third bloom type was the Phaeocystis bloom maximum (e.g. ca Day 145), characterized by large concurrent increases in bacterial cell-specific respiration and growth rates and increasing bacterial and ciliate abundance. Community bacterial growth rate estimates (TTI and changes in cell numbers over $24 \mathrm{~h}$ ) also indicated high bacterial activity and net growth. Maximal bacterial and ciliate abundances were observed the following week (Day 153) when the bacterial cell-specific respiration rate was still elevated. This continuation of elevated bacterial cellspecific respiration rates contrasts with the Rhizosolenia delicatula bloom observations and is the major explanation for the delay between the GCP and DCR maxima. A possible explanation for this persistence of bacterial cell respiration is a change in the major pathway of organic matter transfer to the bacterioplankton from those directly feeding into the LMW pool to those producing HMW material (e.g. phytoplankton lysis (IV) and the HMW forks of the grazing pathways (V and VI)). Our observations of an elevated rate of cell-specific respiration persisting, whilst the bacterial cell-specific tritiated thymidine incorporation rate decreased (i.e. growth efficiency decreased), are consistent with increased bacterial utilization of nitrogen deficient organic material (e.g. carbohydrates). Indeed, very high concentrations of polysaccharides have been reported during Phaeocystis blooms (e.g. Eberlain et al. 1985). Further, the Day 159 time course experiment observations for the $<0.8 \mu \mathrm{m}$ fraction of an increase in bacterial numbers, but linearity in oxygen consumption, are consistent with substrate limitation of the bacterioplankton, with hydrolysis of HMW material constituting the rate limiting step. Bacterial colonization of Phaeocystis bladders was also observed in the sample taken on Day 159. Similar colonization has been reported previously (Putt et al. 1994). Epiphytic bacteria are reported as net releasers of hydrolysate during the decline of a diatom bloom (Middelboe et al. 1995) and thus their activity may have contributed to the LMW pool. Significant flux via an HMW pool during a Phaeocystis bloom was previously inferred by Billen \& Fontigny (1987). The flux of organic matter through the grazing activity of the mesozooplankton during the Phaeocystis bloom was probably small, as only low copepod grazing rates $\left(<1.5 \% \mathrm{~d}^{-1}\right)$ on Phaeocystis have been reported for Liverpool Bay (Claustre et al. 
1990) and the Southern Bight (Hansen \& van Boekel 1991).

In summary, our observations over the 1994 spring bloom period are consistent with 3 distinct phases. An initial mixed diatom bloom with limited transfer of organic material to the bacteria, a Rhizosolenia delicatula bloom with flux of material to the bacteria via an LMW pool, and finally, a Phaeocystis bloom with transfer of material predominantly via an HMW pool. This HMW pool and other temporary storages of non-living organic material (Williams 1995) may support microheterotroph metabolism after the decline of photosynthesis resulting in a temporal positive-negative sequence of net community production.

Our analysis of the basis of the phasing differences in GCP and DCR involved a number of speculations. It nonetheless highlights areas of incomplete understanding (e.g. the partitioning of the DOM pool and the identification of the non-bacterial respirers) and creates an initial framework for modelling and other experimental studies.

Our conclusions demonstrate that the annual microbial cycle for the Menai Strait is comprised of a mixed diatom bloom in late March or April followed by blooms of diatoms and Phaeocystis in May and June. This succession is followed by low phytoplankton biomass and production with intermittent smaller blooms. Size fractionation showed that meso- and microphytoplankton dominated phytoplankton production and biomass over the spring bloom period and nanophytoplankton dominated during summer when activity and biomass were low. Throughout the year, bacterioplankton were shown to be the major respirers and so the phasing of GCP and DCR was strongly influenced by bacterioplankton metabolism and abundance changes. Correlation analysis showed temperature to be the best predictor for chl a-specific GCP. Conversely, bacterial cell-specific metabolic rate parameters were not significantly correlated with temperature. We argue that this is consistent with biological parameters limiting bacterial metabolism rather than temperature. For the mixed diatom bloom in all $3 \mathrm{yr}$, no obvious DCR response was observed. We believe the most likely explanation to be limited transfer of organic material to the bacteria because physical phytoplankton losses predominated. For the exponential phase of the Rhizosolenia delicatula bloom in 1994, unfractionated GCP and DCR maxima occurred in phase; this very close coupling was attributed to the link between the phytoplankton and the bacterioplankton occurring largely via the LMW pool. For the Phaeocystis bloom in all $3 \mathrm{yr}$, there was a delay of 1 to $2 \mathrm{wk}$ between GCP and DCR maxima. Consideration of the 1994 observations attributed this delay to the link between the phytoplankton and the bacterioplankton occurring predominantly via an HMW pool. The consequence of this shift in the partitioning of the DOM pool was that microheterotroph respiration persisted after the decline of photosynthesis and this caused net community production to exhibit a positive-negative temporal sequence.

Acknowledgements. We thank, from the School of Ocean Sciences (SOS), Dave Gill, Michael E. Jones and Elwyn Jones for their skilled construction of equipment, George Jones for making technical staff time available, and lan Pritchard and Matthew Hayes for their help during sampling. We are grateful to Dr Ray Leakey (British Antarctic Survey, BAS) and Dr Maurice Lock (School of Biological Sciences) for their loan of equipment and advice; Dr Ian Lucas (SOS) for his guidance on microplankton identification; Prof. G. E. Fogg and Dr Julian Priddle (BAS) for their critical reading of an earlier manuscript, and Dr Steve Mudge (SOS) and Christine Linaker for their help with the figures. The present research was financially supported by MEICE grant (CEC MAST 2CT 92/003), EROS grant (CEC STEP CT 90/0080), and NERC/BAS (Natural Environment Research Council/British Antarctic Survey) Special topic GST/02/651 awarded to P.J.LeB.W., NERC/BAS special topic grant (BAS/92/ANTIII/2) funding S.P.B., and JNICT (Junta Nacional de Investigação Científica - Portugal) funding R.R. P.J.LeB.W. acknowledges support from the Higher Educational Funding Council for Wales during the period of the preparation of the paper

\section{LITERATURE CITED}

Al-Hasan RH (1976) Seasonal variations in phytoplankton and glycollate concentrations in the Menai Straits, Anglesey. PhD thesis, University of Wales, Bangor

Al-Hasan RH, Coughlan SJ, Pant A, Fogg GE (1975) Seasonal variations in phytoplankton and glycollate concentrations in the Menai Straits, Anglesey. J mar biol Ass UK 55: $557-565$

Bajpai SP (1980) Studies on the relation between photosynthetic rate and chlorophyll content in plankton algae. PhD thesis, University of Wales, Bangor

Baumann M, Lancelot C, Brandini F, Sakshaug E, John D (1994) The taxonomic identity of the cosmopolitan prymnesiophyte Phaeocystis, a morphological and ecophysiological approach. J mar Syst 5:5-22

Bell RT (1988) Thymidine incorporation and estimates of bacterioplankton production: are the conversion factors valid? Arch Hydrobiol Beih Ergeb Limnol 31:163-171

Berger WH, Smetacek VS, Wefer G (1989) Ocean productivity and paleoproductivity - an overview. In: Berger WH, Smetacek VS, Wefer G (eds) Dahlem Workshop on productivity of the ocean: present and past. John Wiley \& Sons, Chichester, p 1-34

Biddanda B, Opsahl S, Benner R (1994) Plankton respiration and carbon flux through bacterioplankton on the Louisiana shelf. Limnol Oceanogr 39:1259-1275

Billen G (1990) Protein degradation in aquatic environments. In: Chróst RJ (ed) Microbial enzymes in aquatic environments. Springer-Verlag, New York, p 123-143

Billen G, Fontigny A (1987) Dynamics of a Phaeocystis-dominated spring bloom in Belgian coastal waters. II. Bacterioplankton dynamics. Mar Ecol Prog Ser 37:249-257

Bjørnsen PK (1988) Phytoplankton exudation of organic matter: 
why do healthy cells do it? Limnol Oceanogr 33:151-154

Chróst RJ (1990a) Microbial ectoenzymes in aquatic environments. In: Overbeck J, Chróst RJ (eds) Aquatic microbial ecology: biochemical and molecular approaches. Springer-Verlag, New York, p 47-78

Chróst RJ (1990b) Environmental control of the synthesis and activity of aquatic microbial ectoenzymes. In: Chróst RJ (ed) Microbial enzymes in aquatic environments. Springer-Verlag, New York, p 29-59

Claustre H, Poulet SA, Williams R, Marty JC, Coombs S, Ben Mlih F, Hapette AM, Martin-Jezequel V (1990) A biochemical investigation of a Phaeocystis sp. bloom in the Irish Sea. J mar biol Ass UK 70:197-207

Ducklow HW, Carlson CA (1992) Oceanic bacterial production. Adv microb Ecol 12:113-181

Ducklow HW, Kirchman DL, Quinby HL (1992) Bacterioplankton cell growth and macromolecular synthesis in seawater cultures during the North Atlantic spring phytoplankton bloom, May, 1989. Microb Ecol 24:125-144

Eberlain K, Leal MT, Hammer KD, Hickel W (1985) Dissolved organic substances during a Phaeocystis pouchetti bloom in the German Bight (North Sea). Mar Biol 89:311-316

Edler L (1979) Recommendations for marine biological studies in the Baltic Sea. Phytoplankton and chlorophyll. Baltic Mar Biol Publ 5:1-38

Ewins PA, Spencer CP (1967) The annual cycle of nutrients in the Menai Strait. J mar biol Ass UK 47:533-542

Fenchel T, Finlay BJ (1983) Respiration rates in heterotrophic, free-living protozoa. Microb Ecol 9:99-122

Fogg GE (1983) The ecological significance of extracellular products of phytoplankton photosynthesis. Botanica mar 26:3-14

Fogg GE, Bajpai SP (1988) Temperature effects on natural phytoplankton populations. In: Round FE (ed) Algae and the aquatic environment. Biopress Ltd, Bristol, p 197-204

Foster P, Voltalina D, Spencer CP, Miller I, Beardall J (1982) A seasonal study of the distributions of surface state variables in Liverpool Bay. III. An offshore front. J exp mar Biol Ecol 58:19-31

Fuhrman J (1987) Close coupling between release and uptake of dissolved free amino acids in seawater studied by an isotope dilution approach. Mar Ecol Prog Ser 37:45-52

Fuhrman JA, Azam F (1980) Bacterioplankton secondary production estimates for coastal waters of British Columbia, Antarctica, and California. Appl environ Microbiol 39: $1085-1095$

Hansen FC, van Boekel WHM (1991) Grazing pressure of the calanoid copepod Temora longicornis on a Phaeocystis dominated spring bloom in Dutch coastal waters. Mar Ecol Prog Ser 78:123-129

Harrison WG (1986) Respiration and its size-dependence in microplankton populations from surface waters of the Canadian Arctic. Polar Biol 6:145-152

Harvey JG (1968) The flow of water through the Menai Strait. Geophys. J R Astrom Soc 15:517-528

Harvey JG (1972) Water temperatures at Menai Bridge pier, 1955-68. Dtsch hydrogr Z 25:202-215

Hopkinson CS (1985) Shallow-water benthic and pelagic metabolism: evidence of heterotrophy in the nearshore Georgia Bight. Mar Biol 87:19-32

Hopkinson CS, Sherr B, Wiebe WJ (1989) Size fractionated metabolism of coastal microbial plankton. Mar Ecol Prog Ser 51:155-166

Iriarte A, Daneri G, Garcia VMT, Purdie DA, Crawford DW (1991) Plankton community respiration and its relationship to chlorophyll a concentration in marine coastal waters. Oceanol Acta 14:379-388
Jones M (1968) Phytoplankton studies in the Menai Strait. MSc thesis, University of Wales, Bangor

Jones M, Spencer CP (1970) The phytoplankton of the Menai Strait. J Cons int Explor Mer 33:169-180

Jones PGW, Haq SM (1963) The distribution of Phaeocystis in the Eastern Irish Sea. J Cons int Explor Mer 28:8-20

Jumars PA, Penry DL, Baross JA, Perry MJ, Frost BW (1989) Closing the microbial loop: dissolved carbon pathway to heterotrophic bacteria from incomplete ingestion, digestion and absorption in animals. Deep Sea Res 36:483-495

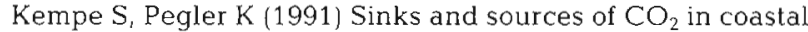
seas: the North Sea. Tellus Ser B 43B:224-235

Kiørboe T (1993) Turbulence, phytoplankton cell size, and the structure of pelagic food webs. In: Blaxter JHS, Southward AJ (eds) Adv mar Biol 29:1-72

Kirk JTO (1994) Light and photosynthesis in aquatic ecosystems. Cambridge University Press, Cambridge, p 119-120

Klein Breteler WCM, Fransz HG, Gonzalez SR (1982) Growth and development of four calaniod copepod species under experimental and natural conditions. Neth $J$ Sea Res 16: $195-207$

Laanbroek HJ, Verplanke JC, de Visscher PRM, de Vuyst R (1985) Distribution of phyto- and bacterioplankton growth and biomass parameters, dissolved inorganic nutrients and free amino acids during a spring bloom in the Oosterschelde basin, the Netherlands. Mar Ecol Prog Ser 25:1-11

Lancelot C, Mathot S (1985) Biochemical fractionation of primary production by phytoplankton in Belgian coastal waters during short- and long-term incubations with ${ }^{14} \mathrm{C}$ bicarbonate. II. Phaeocystis poucheti colonial population. Mar Biol 86:227-232

Lennox AJ (1979) Studies on the ecology and physiology of Phaeocystis. PhD thesis, University of Wales, Bangor

Margalef R (1958) Temporal succession and spatial heterogeneity in phytoplankton. In: Buzzati-Traverso AA (ed) Perspectives in marine biology. University of California Press, Berkeley, p 323-349

Middelboe M, Sondergaard M, Letarte Y, Borch NH (1995) Attached and free-living bacteria: production and polymer hydrolysis during a diatom bloom. Microb Ecol 29: $231-248$

Nagata T, Kirchman DL (1992) Release of dissolved organic matter by heterotrophic protozoa: implications for microbial food webs. Arch Hydrobiol Beih Ergeb Limnol 35 : 99-109

Odum HT (1956) Primary production in flowing waters. Limnol Oceanogr 1:102-117

Parsons TR, Maita Y, Lalli CM (1984) A manual of chemical and biological methods for seawater analysis. Pergamon Press, Oxford

Pomeroy LR, Sheldon JE, Sheldon WM (1994) Changes in bacterial numbers and leucine assimilation during estimations of microbial respiratory rates in seawater by the precision Winkler method. Appl environ Microbiol 60: 328-332

Porter KG, Feig YS (1980) The use of DAPI for identifying and counting aquatic microflora. Limnol Oceanogr 25:943-948

Putt M, Geraldine M, Stoecker D (1994) Association of bacteria with Phaeocystis sp. in McMurdo Sound, Antarctica. Mar Ecol Prog Ser 105:179-189

Rousseau V, Vaulot D, Casoti V, Lenz J, Gunkel J, Baumann $M$ (1994) The life cycle of Phaeocystis (Prymnesiophyceae): evidence and hypotheses. J mar Syst 5:23-29

Savidge G, Kain JM (1990). Productivity of the Irish Sea. In Norton TA, Geffen AJ (eds) The Irish Sea: an environmental review. Part 3: Exploitable living resources. Liverpool University Press, Liverpool, p 9-43 
Shiah FK, Ducklow HW (1994a) Temperature and substrate regulation of bacterial abundance, production and specific growth rate in Chesapeake Bay, USA. Mar Ecol Prog Ser 103:297-308

Shiah FK, Ducklow HW (1994b) Temperature regulation of heterotrophic bacterioplankton abundance, production, and specific growth rate in Chesapeake Bay. Limnol Oceanogr 39:1243-1258

Sieburth JM, Smetacek V, Lenz J (1978) Pelagic ecosystem structure: heterotrophic compartments of the plankton and their relationship to plankton size fractions. Limnol Oceanogr 23:1256-63

Smith EM, Kemp WM (1995) Seasonal and regional variations in plankton community production and respiration for Chesapeake Bay. Mar Ecol Prog Ser 116:217-231

Smith REH, Geider J (1985) Kinetics of intracellular carbon allocation in a marine diatom. J exp mar Biol Ecol 93:191-210

Smith REH, Harrison WG, Irwin B, Platt T (1986) Metabolism and carbon exchange in microplankton of the Grand Banks (Newfoundland). Mar Ecol Prog Ser 34:171-183

Suzuki MT, Sherr EB, Sherr BF (1993) DAPI direct counting underestimates bacterial abundances and average cell size compared to $\mathrm{AO}$ direct counting. Limnol Oceanogr $38: 1566-1570$

Tett P (1987) Plankton. In: Baker JM, Wolff WJ (eds) Biological surveys of estuaries and coasts. Cambridge University Press, Cambridge, p 328-335

Throndsen J (1978) Preservation and storage. In: Sournia A (ed) Monographs on oceanographic methodology. 6: phytoplankton manual. UNESCO, Paris, p 69-74

Tyler PJ (1977) Microbiological and chemical studies of Phaeocystis. PhD thesis, University of Wales, Bangor

Utermöhl H (1958) Zur Vervolkommnung der quantitativen Phytoplankton-Methodik. Mitt int Verein theor angew Limnol 9:1-38

van Boekel WHM, Hansen FC, Riegman R, Bak RPM (1992) Lysis-induced decline of a Phaeocystis spring bloom and coupling with the microbial foodweb. Mar Ecol Prog Ser 81:269-276

This article was presented by F. Rassoulzadegan (Senior Editorial Advisor), Villefranche-sur-Mer, France
Veldhuis MJW, Admiraal W (1985) Transfer of photosynthetic products in gelatinous colonies of Phaeocystis poucheti (Haptophyceae) and its effect on the measurement of excretion rate. Mar Ecol Prog Ser 26:301-304

Vinogradov ME, Shushkina EA (1978) Some development patterns of plankton communities in the upwelling areas of the Pacific Ocean. Mar Biol 48:357-366

Voltalina D, Beardall J, Foster P (1986) The phytoplankton of Liverpool Bay (1977-1979) 4. Geographic distributions and seasonal variations. Nova Hedwigia 43:11-28

Walker TA (1980) A correction to the Poole and Atkins Secchi disc/light-attenuation formula. J mar biol Ass UK 60: $769-771$

Wicks RJ, Robarts RD (1987) The extraction and purification of DNA labelled with [methyl- ${ }^{3} \mathrm{H}$ ] thymidine in aquatic bacterial production studies. J Plankton Res 9:1159-1166

Wiebe WJ, Sheldon WM, Pomeroy LR (1993) Evidence for an enhanced substrate requirement by marine mesophilic bacterial isolates at minimal growth temperatures. Microb Ecol 25:151-159

Williams PJleB (1981) Microbial contribution to overall marine plankton metabolism: direct measurements of respiration. Oceanol Acta 4:359-364

Williams PJleB (1995) Evidence for the seasonal accumulation of carbon-rich dissolved organic material, its scale in comparison with changes in particulate material and the consequential effect on net $\mathrm{C} / \mathrm{N}$ assimilation ratios. Mar Chem 51:17-29

Williams PJleB, Jenkinson NW (1982) A transportable microprocessor-controlled precise Winkler titration suitable for field station and shipboard use. Limnol Oceanogr 27. 576-584

Wright RT, Coffin RB (1984) Measuring microplankton grazing on planktonic marine bacteria by its impact on bacterial production. Microb Ecol 10:137-149

Zweifel UL, Hagström \& (1995) Total counts of marine bacteria include a large fraction of non-nucleoid-containing bacteria (ghosts). Appl environ Microbiol 61: $2180-2185$

Manuscript first received: March 21, 1995

Revised version accepted: September 19, 1995 